\title{
The Relationship Between Management Style Perceptions and Motivation Levels of the Employees Working in Provincial Organizations of the General Directorate of Sports
}

\author{
Yasemin Çakmak Yıldızhan ${ }^{1} \&$ Mehmet Yazıcı ${ }^{1}$ \\ ${ }^{1}$ College of Physical Education and Sport, Erzincan Binali Yıldırım University, Erzincan, Turkey \\ Correspondence: Yasemin Çakmak Yıldızhan, College of Physical Education and Sport, Erzincan Binali Yıldırım \\ University, Erzincan, Turkey. E-mail: ycakmak@erzincan.edu.tr
}

Received: December 20, 2018

Accepted: January 12, 2019

Online Published: February 25, 2019

doi:10.5539/jel.v8n2p117

URL: https://doi.org/10.5539/jel.v8n2p117

This study was presented as oral presentation at the 16th Sports Science Congress.

\begin{abstract}
The purpose of this study was to examine the relationship between management style perceptions and motivation levels of the employees working in provincial organizations of the General Directorate of Sports. The population of the study included the employees carrying on their duties in Provincial Organizations of The General Directorate of Sports, and the sample included totally 407 employees with 112 females and 295 males working in fourteen provinces selected from seven geographical regions of Turkey with a population density representing Turkey. "Management Style Scale" and "Motivation Scale" were used in the study. The "Management Style Scale" (MSS) developed by the researcher included the components and subscales as "authoritarian management style", "protective management style", "supportive management style", "collaborative management style", "laissez-faire management style", and "intrinsic" and "extrinsic" motivation styles developed by Mottaz (1985). T-Test and One-Way Variance Analysis (ANOVA) were used for the analysis of the obtained data. As result, a significant and positive relationship was found between intrinsic motivation and management style sub-dimensions. In addition, a significant and positive relationship was also determined between the dimensions of extrinsic motivation and authoritarian management style and laissez-faire management style.
\end{abstract}

Keywords: management style, motivation, general directorate of sports

\section{Introduction}

The rapid changes experienced in any areas of life have influenced the organizations in various ways; and globalization, destructive competition, rapid developments in computer and communication technology, transition to the information society and considering people as a competitive element have recently shaped the business world and necessitated constant change of organizations (Peker \& Aytürk, 2000). These rapid changes have also appeared in the phenomenon of sports as an inevitable part of the society and indicator of the society's welfare and culture levels, and sport has recently become a branch of science and industry (İmamoğlu, 1992). Although the phenomenon of sports is so important, sport's not being regarded at desired level in Turkey has constantly been discussed and the reason for this has been mentioned to be depending upon the problem of sport management. Just like fulfilling the goals determined for education, health, economy, arts, etc. depends on their management, improving of sport to the desired levels in our country depends on its management with a modern understanding of management, as well. A modern management approach is administered with a style of management employed in organizations. The management style is the interaction between task behavior of the employer while fulfilling the goals and relationship behavior with the employees (Başaran, 2004). It is not possible to discuss management styles independent from the competences, values and roles of the employers. Management style of a manager acquires quality according to his/her attitudes maintained for motivating employees and using the power and attitudes' being towards the organization or employees (Başaran, 1982).

The management styles adopted mainly by the manager in the organization also have important effects on the employees. The management style of a manager is possible to affect affect job satisfaction, organizational efficiency, motivation and organizational commitment of the employees in a positive or negative way (Dick \& 
Metcalfe, 2001). In this sense, the management styles of the sports organizations' managers who are responsible for representing Turkish sport in national and international arena are important for the development of Turkish Sport. The main problem of the study was the relationship between the motivation levels and management style perceptions of the employees carrying on their duties in provincial organizations of the General Directorate of Sports.

Thus, the management style perceptions of the employees in the provincial organization of the General Directorate of Sports were determined, then whether the administered management style affected the motivation of employees or not was revealed. Firstly, the management style and motivation concepts were briefly explained, and subsequently the method of study, data collection tools, data analysis and findings were included in the study.

\subsection{Management Style}

Manager behavior is the behavior of being able to put individuals and groups into action and direct them to predetermined targets (Bursalıoglu, 1994). One of the most important factors of the management is the managerial behavior of the manager which means the management style of the manager. Management style is a behavioral pattern that forms through the interaction of the relationship behavior with the employees and the task behavior the manager shows when fulfilling her/his goals. Management style is a kind of managerial behavior specific to the manager (Başaran, 2004).

Management style is the result of managers, employees and managerial environment. In other words, employers, employees and environment are the factors for the management style. The managers have individual-specific managerial behaviors they display in their organization according to the belief influenced by their views, management theory they are influenced, and their personality traits (Başaran, 2008). Management style of the manager includes values system, leadership tendency, trust on employees and trust feeling of the managers (Hersey \& Blanchard, 1982).

It is not possible to discuss management styles independent from competences, roles and value judgments of the managers. The management style of the organization directly affects the organizational behavior of the employee. The most important factor determining and shaping the type of management behavior is the employers' way of using their authority. Belief, feelings, views and values the managers have towards people, organization and management create their management styles affecting their understanding and administering the management (Başaran, 1982).

In management, "human" and "duty" are two main elements. These two factors are two fundamental elements that complement each other. Because a person carries out a task, or the task is carried out by a person. Therefore, the task (production of goods or services) is based on the person. All management and management styles and behaviors are always shaped according to these two basic elements. All managers are evaluated accordingly (Urlu, 2002). Considering these two elements, the management styles are classified according to certain criteria by different field experts. Paletta and Vidoni (2006) listed management models and leadership styles. These are management model of procedures, colleague management model, organizational anarchy model, politic management model and management of goals model (Palette \& Vidoni, 2006). Another classification on management styles was Likert's System 4 approach. These are classified as exploitive-autocratic, benevolent-autocratic, participatory and democratic (Likert, 1967). The management styles developed and classified by Robert R. Blake and Jane S. Mouton are authoritarian, humanistic, following middle way policy, liberal thought, democratic and participatory management style (Cem, 1971).

As discussed earlier, various management styles are adopted in organizations. In this study, management styles called as authoritarian, protective, supportive and collaborative and grouped in four clusters were included. In addition, although it is not a theory, the laissez-faire management style was introduced in this study because it was encountered in some organizations (Başaran, 2004).

Authoritarian management style, is a theory that has been used throughout history and still has quite supporters today. The authoritarian theory has principles and rules based upon absolute power (Başaran, 1982), and defends an oppressive management due to the patriarchal regime. According to this management style, all management authority should be in the hands of senior management of the organization, and subordinates must follow the instructions of the manager unconditionally. In authoritarian management, the basis for the managerial power of the manager is more laws and his/her authority (Başaran, 2008). In this management style, the main purpose of the manager is to produce goods and service. Authoritative managers regard the factor of task more than human. What the authoritarian managers mainly want is the person's producing at the maximum level. According to this thought, the person does not work if she/he is left alone. Being nice to person leads to 
exploitation and provides benefit only if the person is managed only authoritatively (Urlu, 2002). The authoritarian manager wants to be consulted and asked for his/her permission for all subjects (Öztekin, 2002).

Protective management style, defends Neo-classical management approach assuming the idea of foregrounding the person (Cem, 1971). The protective management style prioritizes meeting the needs of the employees, make them feel secured, feel satisfied with their own work rather than achieving the goals of the institute (Erdoğan, 2004). In this management style, the power source is the economic resources under the responsibility of the manager. The manager aims to provide the economic satisfaction of the employee and let them be connected to the organization and spend their power for achieving the goals of the organization (Davis, 1988). In this management style, the managers have the value judgment that if no pressure and control is strained on them the employees and they are treated nice, the employee work more productive and be happier in the office. In management, such managers are generally called "friendly managers" (Aytürk, 2003).

Supportive management style, is likened to Mc Gregor's theory of $Y$ as it is likened to Rensis Likert's management systems approach. The Y theory has drawn a creative profile of the employee who enjoys working, taking responsibility and managing, who are motivated for prestige, and suggest important clues about the feeling of trust. As in the authoritarian and protective theory, the supportive theory is based on the idea of leadership and psychological expectations also need to be satisfied rather than the authoritative and economic resources. In this management style, it is assumed that the manager contributes upon the organization when s/he carried out works in the organization according to every employee's interests and competencies in an environment $\mathrm{s} /$ he develops within the organization with the leadership qualities (Davis, 1981). Supportive managers treat the employees equally, pay attention to the relationships between individuals and groups, and take care of the welfare and needs of the employees (Tosi, Rizzo, \& Carrol, 1995).

Collaborative management style, is a theory that appears with the increase at scientists and professionalists in organizations. The demands of scientists and professionalists to work independently in the organizations, the qualities they have such as having intellectual specialties, their desire for working in professional organizations, and their responsibilities of self-management have forced managers to adopt a different style of the management (Başaran, 1982). The popularization of system approach in the organizations and the adoption of contingency theory in management have also helped to reveal this style of management (Başaran, 2004). The collaborative management style is a more developed and expanded style of the supportive management style (Davis, 1981). This management style based on self-control and self-management of the employee is a management style convenient for the complete teamwork providing self-actualization requirements of the employees. The source of collaborative management is managers' expertise and organizational leadership in production issues. The collaborative manager does not apply to the legal and authority powers, but acts as a member of the team as s/he leaves her/his managerial power to the employees (Başaran, 2004). In collaborative management, the manager believes that success is the factor for influencing, encouraging and motivating the employees (Kazmier, 1979).

Laissez-faire management style, although laissez-faire management style is known as a form of leadership in many sources, it is not actually a managerial behavior theory. However, this management style, the manager refrains from using the power in her/his hand, everyone can do whatever s/he wants to do, that there is no policy and rules, and found in some organizations (Hersey \& Blanchard, 1982). In the laissez-faire management style, which is also called as liberal management style, the employees seem to work from outside, but the employees have a minute amount of contribution to the aims of the organization. The employee is told what to do once and then the employee is supposed to work, and left alone. The employee does the job as s/he knows and has definitely no inferences $(\mathrm{Cem}, 1971)$. These kinds of managers are in a position indicating that they do not want the employee to expect much from themselves, and they do not expect much from the employees, as well (Aytürk, 2003).

When the management styles discussed in the study was evaluated in general, it was noticed that each management style gained qualification according to the organization that was administered and to the position of the organization. There is no single correct way to manage organizations. This depends more on historical conditions, on the purpose of the organization and, most importantly, on the appropriateness between the views of the management on the person and the real characteristics of the members of organization. The manager's thoughts (Schein, 1978), knowledge, skill and experience about the employee create his managerial behavior, and his management style identity. The style of management is contingent and there is no best way for the manager. According to Contingency Theory, no style of government is bad. If a management style is not appropriate for the production of the organization and not suitable for the qualification of the employee, only then the management style is called as bad (Başaran, 2004). 


\subsection{Motivation}

Today, one of the main objectives of businesses and organizations is to increase productivity and one way of this is to select the appropriate motivation tools motivating the employee, to increase their motivation and to provide continuation of this situation (Akat, 1994). The word motivation basically means motion (Adair, 2003), comes from the old Latin word "movere" which means "move", and is defined as an energy that directs and determines the human behavior (Şimşek, Akgemci, \& Çelik, 2003). Motivation is defined as a person or group's inducing to set efforts for motion, to maintain and to manage this and to make it gain importance (Latham \& Pinder, 2005). Motivation refers to a process that starts with physiological and psychological needs and set the behavior that will lead the goal to be in motion (Luthans, 2001). There is a demand under all behaviors, and it is necessary to satisfy the demands of the people to achieve the goals. In terms of the source of the power that puts the individual in motion, motivation is generally considered in two dimensions as intrinsic and extrinsic.

Intrinsic motivation, according to intrinsic motivation, the employees are motivated by the work itself and there is no external control regulating the behavior of the person. This style of motivation is defined as the experience of the individual to demonstrate her/his own abilities (Brief \& Aldag, 1976). Intrinsic motivation tools are directly related to the nature of the work and originate from the content of the work. It includes factors such as interesting and compelling work, independence at work, the importance of the job in terms of the employee, participation in work, responsibility, diversity, creativity, opportunities of person to use her/his abilities and skills, and satisfactory feedback related to person's performance (Mottaz, 1985). In short, the intrinsic motivation is based on the basis of an individual's voluntary activity, and therefore, when a person acts with intrinsic motivation, s/he acts more easily and with satisfaction (Nurcahyo, Nur'ainy, \& Sariyati, 2011).

Extrinsic motivation, involves the influences that come from the individual's environment. Extrinsic rewards such as an employee's receiving payment due to her/his performance, premiums, promotion and her/his appreciation by the manager increase motivation. Although the role of extrinsic factors in motivation is important, extrinsic factors often cannot provide the required motivation without intrinsic factors (Ertürk, 2016). Extrinsic motivation tools have two dimensions. These are related to social motivation tools and organizational tools. The dimension of the social motivation includes factors such as friendship, helpfulness, support of the colleagues and managers, and is based upon the quality of interpersonal relations. The other dimension of the extrinsic motivation tools is the organizational dimension that deals with the opportunities offered by the organization to improve work performance. These tools are concrete and include factors such as the sufficiency of the resources in work environment, the appropriateness of physical conditions in work environment, salary equality, premiums, rewards, promotion opportunity and job security (Mottaz, 1985).

As could be understood from the statements above, while intrinsic and extrinsic motivation tools are different in content, it has been accepted that intrinsic and extrinsic motivation tools have a positive effect on the motivation of employees. Whereas the work itself motivates the individuals in intrinsic motivation, the factors that come from the environment motivate the individuals in the extrinsic motivation.

\section{Method}

In this study, general survey model which examined the relationship between the management styles perceptions and the motivation levels of the employees working in the provincial organization of the General Directorate of Sports was used. First of all, the management styles perceptions and motivation levels of the employees working in the provincial organization of the General Directorate of Sports were discussed in terms of gender, age, educational status, period of service, position title, and participation in in-service trainings. Then the relationship between the two variables was examined.

\subsection{Population and Sample}

The population of the study included the employees carrying on their duties in Provincial Organizations of The General Directorate of Sports, and the sample included employees selected from seven geographical regions of Turkey with a population density representing Turkey. Totally 407 provincial directorate employees participated into our study.

\subsection{Data Collection Tools}

In the study, Personal Information Form, "Management Style Scale" and "Motivation Level Determination Scale" were used as data collection tools.

Mottaz's (1985) "Motivation Scale" was used in order to determine the motivation level of the employees. There were totally 24 items in the scale (Mottaz, 1985). The scale included two sub-dimensions. The items between 1 and 9 measured "intrinsic motivation", and the items between 10 and 24 measured "extrinsic motivation". The 
overall reliability of the scale was found to be highly reliable as 0.85 . When the reliability of the sub-dimensions of the scale was examined, the reliability of the "intrinsic motivation" sub-dimension was found to be $\alpha=0.867$, and the reliability of the "external motivation" was $\alpha=0.840$.

The Motivation Scale was graded according to 5-point Likert type including the statements of "strongly disagree", "disagree", "moderately agree", "agree" and "strongly agree",

"Management Style Scale" developed by Y1ldizhan was used in order to determine management style perceptions of the employees. There were totally 42 items in the scale. The scale included five sub-dimensions. $1^{\text {st }}, 2^{\text {nd }}, 3^{\text {rd }}, 4^{\text {th }}, 5^{\text {th }}, 6^{\text {th }}, 7^{\text {th }}, 8^{\text {th }}$, and $9^{\text {th }}$ items included “Authoritarian Management Style" $10^{\text {th }}, 11^{\text {th }}, 12^{\text {th }}, 13^{\text {th }}, 14^{\text {th }}$, $15^{\text {th }}, 16^{\text {th }}, 17^{\text {th }}, 18^{\text {th }}$ and $19^{\text {th }}$ items included "Protective Management Style", $20^{\text {th }}, 21^{\text {st }}, 22^{\text {nd }}, 23^{\text {rd }}, 24^{\text {th }}, 25^{\text {th }}, 26^{\text {th }}$, $27^{\text {th }}, 28^{\text {th }}$ and $29^{\text {th }}$ items included "Supportive Management Style", $29^{\text {th }}, 30^{\text {th }}, 31^{\text {st }}, 32^{\text {nd }}, 33^{\text {rd }}, 34^{\text {th }}, 35^{\text {th }}$, and $36^{\text {th }}$ items included "Collaborative Management Style", and $37^{\text {th }}, 38^{\text {th }}, 39^{\text {th }}, 40^{\text {th }}, 41^{\text {st }}$, and $42^{\text {nd }}$ items included "Laissez-faire Management Style". The overall reliability of the scale was found to be 0.88 . When the reliability of the sub-dimensions of the scale was analyzed, it was noticed that the reliability of the sub-dimension of The Authoritarian Management Style was $\alpha=0.76$, the reliability of The Supportive Management Style was $\alpha=0.89$, the reliability of The Collaborative Management Style was $\alpha=0.87$, the reliability of The Protective Management Style was $\alpha=0.79$, and the reliability of The Laissez-faire Management Style was $\alpha=0.72$.

The Management Style Scale was graded according to 7-point Likert scale indicating expressions from "Strongly Disagree" to "Strongly Agree" (Strongly Disagree, Mostly Disagree, Disagree, Undecided, Agree, Mostly Agree, Strongly Agree).

\subsection{Data Analysis}

According to the variable of "gender", t-test was performed for the independent groups in order to reveal the difference in the management style perceptions and motivations levels of the employees working in provincial organizations of the General Directorate of Sports, and one-way variance analysis (ANOVA) was performed in order to reveal the difference according to the variables such as "age", "educational status", "duration of service", "position title" and "participation in in-service trainings". Levene's test was used to determine whether the variances were homogeneous or not. In addition, LSD test was performed as an advanced statistical technique in order to determine the source of difference appeared as result of the ANOVA test. Pearson's correlation coefficient was used in order to prove the relationship between the management style perceptions and motivation level sub-dimensions. The level of significance was regarded to be .05 in the study.

\section{Findings}

In this section of the study, the findings obtained from the statistical analysis of the data were presented. The results of independents groups t-test performed for revealing the differentiation of employees' management style perceptions and motivations levels were presented in Table 1.

Table 1. Distribution of employees' management style perceptions and motivation levels according to gender

\begin{tabular}{|c|c|c|c|c|c|c|c|}
\hline & Variables & Gender & $\mathrm{n}$ & $\overline{\mathrm{X}}$ & Std. Dev. & $\mathrm{t}$ & $\mathrm{p}$ \\
\hline \multirow[t]{10}{*}{ Management Styles } & \multirow[t]{2}{*}{ Authoritarian } & Female & 112 & 3.63 & 1.35 & \multirow[t]{2}{*}{-.779} & \multirow[t]{2}{*}{.436} \\
\hline & & Male & 295 & 3.74 & 1.21 & & \\
\hline & \multirow[t]{2}{*}{ Protective } & Female & 112 & 5.29 & 1.23 & \multirow[t]{2}{*}{-.515} & \multirow[t]{2}{*}{.607} \\
\hline & & Male & 295 & 5.35 & 1.11 & & \\
\hline & \multirow[t]{2}{*}{ Supportive } & Female & 112 & 5.61 & 1.41 & \multirow[t]{2}{*}{-.370} & \multirow[t]{2}{*}{.711} \\
\hline & & Male & 295 & 5.67 & 1.27 & & \\
\hline & \multirow[t]{2}{*}{ Collaborative } & Female & 112 & 5.31 & 1.33 & \multirow[t]{2}{*}{-1.345} & \multirow{2}{*}{.180} \\
\hline & & Male & 295 & 5.49 & 1.16 & & \\
\hline & \multirow[t]{2}{*}{ Laissez-faire } & Female & 112 & 3.50 & 1.23 & \multirow[t]{2}{*}{-2.095} & \multirow[t]{2}{*}{$.037 *$} \\
\hline & & Male & 295 & 3.81 & 1.38 & & \\
\hline \multirow[t]{4}{*}{ Work Motivation } & \multirow[t]{2}{*}{ Intrinsic Motivation } & Female & 112 & 3.59 & .80 & \multirow[t]{2}{*}{-1.148} & \multirow[t]{2}{*}{.252} \\
\hline & & Male & 295 & 3.70 & .88 & & \\
\hline & \multirow[t]{2}{*}{ Extrinsic Motivation } & Female & 112 & 3.14 & .67 & \multirow[t]{2}{*}{-1.194} & \multirow[t]{2}{*}{.233} \\
\hline & & Male & 295 & 3.23 & .74 & & \\
\hline
\end{tabular}


As could be seen in Table 1, as a result of the t-test which was performed to determine whether the management style perceptions and work motivation levels of the employees working in the provincial organization of the General Directorate of Sports have differed according to gender or not, it was determined that only the dimension of laissez-faire management style $(\mathrm{t}=-2.095 ; \mathrm{p}<.05)$ differed significantly in favor of the male employees.

In addition, it was determined that there were no significant differences in the dimensions of intrinsic motivation $(\mathrm{t}=-1.148 ; \mathrm{p}>.05)$ and extrinsic motivation $(\mathrm{t}=-1.194 ; \mathrm{p}>.05)$ in terms of gender.

One-way ANOVA and LSD test results performed to reveal the difference of management style perceptions and motivation levels of the employees carrying on their duties in provincial organization of General Directorate of Sports according to age were presented in Table 2.

Table 2. Distribution of employees' management style perceptions and motivation levels according to age

\begin{tabular}{|c|c|c|c|c|c|c|c|c|c|}
\hline & Variables & & Age & $\mathrm{n}$ & $\overline{\mathrm{X}}$ & Std. Dev. & $F$ & $\mathrm{p}$ & LSD \\
\hline \multirow[t]{30}{*}{ Management Styles } & \multirow[t]{6}{*}{ Authoritarian } & A & $20-25$ age & 43 & 3.64 & 1.24 & \multirow[t]{6}{*}{2.199} & \multirow[t]{6}{*}{.054} & \multirow[t]{6}{*}{ - } \\
\hline & & B & 26-30 age & 134 & 3.71 & 1.14 & & & \\
\hline & & $\mathrm{C}$ & $31-35$ age & 87 & 3.53 & 1.38 & & & \\
\hline & & $\mathrm{D}$ & $36-40$ age & 45 & 3.62 & 1.46 & & & \\
\hline & & E & $41-45$ age & 25 & 3.40 & 1.34 & & & \\
\hline & & $\mathrm{F}$ & 46 age and older & 73 & 4.10 & 1.05 & & & \\
\hline & \multirow[t]{6}{*}{ Protective } & A & $20-25$ age & 43 & 5.16 & 1.46 & \multirow[t]{6}{*}{1.636} & \multirow[t]{6}{*}{.149} & \multirow[t]{6}{*}{-} \\
\hline & & B & 26-30 age & 134 & 5.39 & 1.06 & & & \\
\hline & & $\mathrm{C}$ & $31-35$ age & 87 & 5.18 & 1.23 & & & \\
\hline & & $\mathrm{D}$ & $36-40$ age & 45 & 5.68 & .95 & & & \\
\hline & & E & $41-45$ age & 25 & 5.11 & 1.55 & & & \\
\hline & & $\mathrm{F}$ & 46 age and older & 73 & 5.39 & .90 & & & \\
\hline & \multirow[t]{6}{*}{ Supportive } & A & $20-25$ age & 43 & 5.48 & 1.57 & \multirow[t]{6}{*}{1.693} & \multirow[t]{6}{*}{.135} & \multirow[t]{6}{*}{-} \\
\hline & & B & 26-30 age & 134 & 5.68 & 1.30 & & & \\
\hline & & $\mathrm{C}$ & $31-35$ age & 87 & 5.51 & 1.33 & & & \\
\hline & & $\mathrm{D}$ & $36-40$ age & 45 & 6.05 & 1.06 & & & \\
\hline & & E & $41-45$ age & 25 & 5.29 & 1.66 & & & \\
\hline & & $\mathrm{F}$ & 46 age and older & 73 & 5.75 & 1.06 & & & \\
\hline & \multirow[t]{6}{*}{ Collaborative } & A & $20-25$ age & 43 & 5.16 & 1.36 & \multirow[t]{6}{*}{2.318} & \multirow[t]{6}{*}{$.043^{*}$} & $\mathrm{~A}<\mathrm{D}$ \\
\hline & & B & 26-30 age & 134 & 5.45 & 1.19 & & & $\mathrm{~B}<\mathrm{D}$ \\
\hline & & $\mathrm{C}$ & $31-35$ age & 87 & 5.35 & 1.26 & & & $\mathrm{C}<\mathrm{D}$ \\
\hline & & $\mathrm{D}$ & $36-40$ age & 45 & 5.87 & 1.14 & & & $E<D$ \\
\hline & & E & $41-45$ age & 25 & 5.08 & 1.48 & & & \\
\hline & & $\mathrm{F}$ & 46 age and older & 73 & 5.57 & .96 & & & \\
\hline & \multirow[t]{6}{*}{ Laissez-faire } & A & $20-25$ age & 43 & 3.58 & 1.46 & \multirow[t]{6}{*}{.408} & \multirow[t]{6}{*}{.844} & \multirow[t]{6}{*}{-} \\
\hline & & B & 26-30 age & 134 & 3.68 & 1.37 & & & \\
\hline & & $\mathrm{C}$ & $31-35$ age & 87 & 3.71 & 1.36 & & & \\
\hline & & $\mathrm{D}$ & $36-40$ age & 45 & 3.73 & 1.42 & & & \\
\hline & & $\mathrm{E}$ & $41-45$ age & 25 & 3.69 & 1.22 & & & \\
\hline & & $\mathrm{F}$ & 46 age and older & 73 & 3.91 & 1.22 & & & \\
\hline \multirow[t]{12}{*}{ Work Motivation } & \multirow[t]{6}{*}{ Intrinsic Motivation } & A & $20-25$ age & 43 & 3.61 & .87 & \multirow[t]{6}{*}{3.901} & $.002 *$ & $\mathrm{~A}<\mathrm{F}$ \\
\hline & & B & 26-30 age & 134 & 3.64 & .79 & & & $\mathrm{~B}<\mathrm{F}$ \\
\hline & & $\mathrm{C}$ & $31-35$ age & 87 & 3.54 & .89 & & & $\mathrm{C}<\mathrm{F}$ \\
\hline & & $\mathrm{D}$ & $36-40$ age & 45 & 3.81 & .79 & & & $\mathrm{E}<\mathrm{F}$ \\
\hline & & $\mathrm{E}$ & $41-45$ age & 25 & 3.23 & 1.12 & & & $\mathrm{E}<\mathrm{B}$ \\
\hline & & $\mathrm{F}$ & 46 age and older & 73 & 3.97 & .80 & & & $E<D$ \\
\hline & Extrinsic Motivation & A & $20-25$ age & 43 & 3.37 & .66 & 2.257 & $.048^{*}$ & $\mathrm{D}<\mathrm{A}$ \\
\hline & & B & 26-30 age & 134 & 3.21 & .61 & & & $\mathrm{E}<\mathrm{A}$ \\
\hline & & $\mathrm{C}$ & $31-35$ age & 87 & 3.12 & .83 & & & $\mathrm{C}<\mathrm{F}$ \\
\hline & & $\mathrm{D}$ & $36-40$ age & 45 & 3.06 & .80 & & & $\mathrm{D}<\mathrm{F}$ \\
\hline & & E & $41-45$ age & 25 & 2.99 & .74 & & & $\mathrm{E}<\mathrm{F}$ \\
\hline & & $\mathrm{F}$ & 46 age and older & 73 & 3.37 & .71 & & & \\
\hline
\end{tabular}

Note. ${ }^{*} \mathrm{p}<.05$. 
As could be seen in Table 2, as result of the one-way variance analysis (ANOVA) which was performed to determine whether the management style perceptions and work motivation levels of the employees working in the provincial organization of the General Directorate of Sports differed according to age, it was determined that only the dimension of collaborative management style $(\mathrm{F}=2.318 ; \mathrm{p}<.05)$ differed significantly according to the age.

In addition, it was determined that the intrinsic motivation $(\mathrm{F}=3.901 ; \mathrm{p}<.05)$ and extrinsic motivation $(\mathrm{F}=2.257$; $\mathrm{p}<.05)$ dimensions among the sub-dimension of work motivation of the employees working in the provincial organization of the General Directorate of Sports differed significantly according to age. For determining the source of these differences, the Levene's test was performed to examine whether the variances were homogeneous or not before performing the multiple comparison test. It was found that the variances in the dimensions of the collaborative management style $\left(\mathrm{L}_{\mathrm{F}}=1.452 ; \mathrm{p}>.05\right)$, intrinsic motivation $\left(\mathrm{L}_{\mathrm{F}}=1.397 ; \mathrm{p}>.05\right)$ and extrinsic motivation $\left(\mathrm{L}_{\mathrm{F}}=1.976 ; \mathrm{p}>.05\right)$ were homogeneous; and the LSD was used to determine the significant difference in these dimensions.

When Table 2 was analyzed, the score averages of the of the employee in the 36-40 age group for collaborative management style sub-dimension as one of the management style sub-dimensions ( $\bar{X}=5.87$; SS=1.14) were found to be higher than the employees in the 20-25 age group ( $\bar{X}=5.16$; SS=1.36), 26-30 age group ( $\bar{X}=5.45$; $\mathrm{SS}=1.19), 31-35$ age group $(\bar{X}=5.35 ; \mathrm{SS}=1.26)$ and $41-45$ age group $(\bar{X}=5.08 ; \mathrm{SS}=1.48)$.

In the intrinsic motivation dimension of the work motivation scale, while averages of the employees in 46 years and older ( $\bar{X}=3.97$; SS $=.80$ ) were determined to be higher than the employees in the 20-25 age group $(\bar{X}=3.61$; $\mathrm{SS}=.87), 26-30$ age group $(\bar{X}=3.64 ; \mathrm{SS}=.79), 31-35$ age group $(\bar{X}=3.54 ; \mathrm{SS}=.89)$ and $41-45$ age group $(\bar{X}=3.23$; $\mathrm{SS}=1.12)$, the averages of the employees in the $41-45$ age group $(\bar{X}=3.23 ; \mathrm{SS}=1.12)$ were determined to be lower than the employees in the 26-30 age group $(\bar{X}=3.64 ; \mathrm{SS}=.79)$ and $36-40$ age group $(\bar{X}=3.82 ; \mathrm{SS}=.79)$. In the extrinsic motivation dimension, whereas the score averages of the employees in the $20-25$ age group ( $\bar{X}$ $=3.37 ; \mathrm{SD}=.66)$ and 46 years and older group $(\bar{X}=3.37 ; \mathrm{SD}=.71)$ were noticed to be higher than the employees in the 36-40 age group $(\bar{X}=3.06 ; \mathrm{SD}=.80)$ and $41-45$ age group $(\bar{X}=2.99 ; \mathrm{SD}=.74)$, the averages of the employee in 46 years and older $(\bar{X}=3.37 ; \mathrm{SD}=.71)$ were determined to be higher rather than the employees in the 31-35 age group $(\bar{X}=3.12 ; \mathrm{SS}=.83)$.

One-way ANOVA and LSD test results performed to reveal the difference of management style perceptions and motivation levels of the employees carrying on their duties in provincial organization of General Directorate of Sports according to educational status were presented in Table 3.

Table 3. Distribution of employees' management style perceptions and motivation levels according to education

\begin{tabular}{|c|c|c|c|c|c|c|c|c|c|}
\hline & Variables & & Education & $\mathrm{n}$ & $\overline{\mathrm{X}}$ & Std. Dev. & $\mathrm{F}$ & $\mathrm{p}$ & LSD \\
\hline \multirow[t]{15}{*}{ Management Styles } & \multirow[t]{3}{*}{ Authoritarian } & $\mathrm{A}$ & Secondary School & 80 & 4.04 & 1.25 & \multirow[t]{3}{*}{3.660} & \multirow[t]{3}{*}{$.027 *$} & \multirow[t]{3}{*}{$\mathrm{B}<\mathrm{A}$} \\
\hline & & B & Bachelor's Degree & 294 & 3.61 & 1.24 & & & \\
\hline & & $\mathrm{C}$ & Master's Degree & 33 & 3.74 & 1.22 & & & \\
\hline & \multirow[t]{3}{*}{ Protective } & A & Secondary School & 80 & 5.18 & 1.27 & \multirow[t]{3}{*}{.925} & \multirow[t]{3}{*}{.397} & \multirow[t]{3}{*}{-} \\
\hline & & B & Bachelor's Degree & 294 & 5.38 & 1.11 & & & \\
\hline & & $\mathrm{C}$ & Master's Degree & 33 & 5.35 & 1.15 & & & \\
\hline & \multirow[t]{3}{*}{ Supportive } & A & Secondary School & 80 & 5.41 & 1.52 & \multirow[t]{3}{*}{1.770} & \multirow[t]{3}{*}{.172} & \multirow[t]{3}{*}{-} \\
\hline & & B & Bachelor's Degree & 294 & 5.72 & 1.24 & & & \\
\hline & & $\mathrm{C}$ & Master's Degree & 33 & 5.69 & 1.31 & & & \\
\hline & \multirow[t]{3}{*}{ Collaborative } & A & Secondary School & 80 & 5.28 & 1.33 & \multirow[t]{3}{*}{.935} & \multirow[t]{3}{*}{.393} & \multirow[t]{3}{*}{-} \\
\hline & & B & Bachelor's Degree & 294 & 5.48 & 1.18 & & & \\
\hline & & $\mathrm{C}$ & Master's Degree & 33 & 5.49 & 1.21 & & & \\
\hline & \multirow[t]{3}{*}{ Laissez-faire } & A & Secondary School & 80 & 3.79 & 1.35 & \multirow[t]{3}{*}{1.116} & \multirow[t]{3}{*}{.329} & \multirow[t]{3}{*}{-} \\
\hline & & B & Bachelor's Degree & 294 & 3.67 & 1.35 & & & \\
\hline & & $\mathrm{C}$ & Master's Degree & 33 & 4.03 & 1.28 & & & \\
\hline \multirow[t]{6}{*}{ Work Motivation } & \multirow[t]{3}{*}{ Intrinsic Motivation } & A & Secondary School & 80 & 3.67 & 1.03 & \multirow[t]{3}{*}{1.816} & \multirow[t]{3}{*}{.164} & \multirow[t]{3}{*}{-} \\
\hline & & B & Bachelor's Degree & 294 & 3.64 & .82 & & & \\
\hline & & $\mathrm{C}$ & Master's Degree & 33 & 3.94 & .74 & & & \\
\hline & \multirow{3}{*}{ Extrinsic Motivation } & A & Secondary School & 80 & 3.22 & .72 & \multirow[t]{3}{*}{.147} & \multirow[t]{3}{*}{.863} & \multirow[t]{3}{*}{-} \\
\hline & & B & Bachelor's Degree & 294 & 3.20 & .72 & & & \\
\hline & & $\mathrm{C}$ & Master's Degree & 33 & 3.26 & .70 & & & \\
\hline
\end{tabular}


As could be seen in Table 3, the management style perceptions and work motivation levels of the employees working in the provincial organization of the General Directorate of Sports was noticed to differ significantly only in the dimension of authoritarian management style $(\mathrm{F}=3.660 ; \mathrm{p}<.05)$ in terms of educational status. It was determined that there were no significant differences in the work motivation sub-dimension for the employees working in the provincial organization of the General Directorate of Sports according to educational status. To determine the source of this difference, the Levene's test was used for analyzing whether the variances were homogeneous before performing the multiple comparison test. It was found that the variances in the dimension of authoritarian management style $\left(\mathrm{L}_{\mathrm{F}}=.015 ; \mathrm{p}>.05\right)$ to be homogeneous; and the LSD was used to determine among which groups there was a significant difference. When Table 3 was analyzed, it was determined that the score averages of the authoritarian management style sub-dimension $(\bar{X}=4.04 ; \mathrm{SD}=1.25)$ as one of the management style sub-dimensions for the secondary school graduated employees were found to be higher rather than the university graduated employees $(\bar{X}=3.61 ; \mathrm{SD}=1.24)$.

One-way ANOVA and LSD test results performed to reveal the difference of management style perceptions and motivation levels of the employees carrying on their duties in provincial organization of General Directorate of Sports according to their duration of service were presented in Table 4.

Table 4. Distribution of employees' management style perceptions and motivation levels according to their duration of service

\begin{tabular}{|c|c|c|c|c|c|c|c|c|c|}
\hline \multirow{2}{*}{ Management Styles } & \multirow{2}{*}{$\begin{array}{l}\text { Variables } \\
\text { Authoritarian }\end{array}$} & \multicolumn{2}{|c|}{ Duration of Service } & & \multirow{2}{*}{$\frac{\bar{X}}{3.54}$} & \multirow{2}{*}{$\frac{\text { Std. Dev. }}{1.16}$} & \multirow{2}{*}{$\frac{F}{3.701}$} & \multirow{2}{*}{$\frac{\mathrm{p}}{.006^{*}}$} & \multirow{2}{*}{$\begin{array}{l}\mathrm{LSD} \\
\mathrm{A}<\mathrm{B}\end{array}$} \\
\hline & & $\mathrm{A}$ & $0-5$ years & & & & & & \\
\hline & & $\mathrm{B}$ & $6-10$ years & 55 & 3.97 & 1.49 & & & $\mathrm{~A}<\mathrm{E}$ \\
\hline & & $\mathrm{C}$ & $11-15$ years & 36 & 3.60 & 1.44 & & & $\mathrm{C}<\mathrm{E}$ \\
\hline & & $\mathrm{D}$ & $16-20$ years & 22 & 3.87 & 1.38 & & & \\
\hline & & $\mathrm{E}$ & 21 and over years & 55 & 4.16 & 1.04 & & & \\
\hline & Protective & A & $0-5$ years & 239 & 5.37 & 1.15 & 1.111 & .351 & - \\
\hline & & $\mathrm{B}$ & $6-10$ years & 55 & 5.29 & 1.26 & & & \\
\hline & & $\mathrm{C}$ & $11-15$ years & 36 & 5.21 & 1.05 & & & \\
\hline & & $\mathrm{D}$ & $16-20$ years & 22 & 4.93 & 1.64 & & & \\
\hline & & $\mathrm{E}$ & 21 and over years & 55 & 5.49 & .81 & & & \\
\hline & Supportive & A & $0-5$ years & 239 & 5.69 & 1.32 & 1.052 & .380 & - \\
\hline & & $\mathrm{B}$ & $6-10$ years & 55 & 5.51 & 1.32 & & & \\
\hline & & $\mathrm{C}$ & $11-15$ years & 36 & 5.49 & 1.35 & & & \\
\hline & & $\mathrm{D}$ & $16-20$ years & 22 & 5.32 & 1.72 & & & \\
\hline & & $\mathrm{E}$ & 21 and over years & 55 & 5.85 & .97 & & & \\
\hline & Collaborative & A & $0-5$ years & 239 & 5.45 & 1.25 & .446 & .775 & - \\
\hline & & B & $6-10$ years & 55 & 5.41 & 1.13 & & & \\
\hline & & $\mathrm{C}$ & $11-15$ years & 36 & 5.26 & 1.26 & & & \\
\hline & & $\mathrm{D}$ & $16-20$ years & 22 & 5.36 & 1.67 & & & \\
\hline & & $\mathrm{E}$ & 21 and over years & 55 & 5.59 & .85 & & & \\
\hline & Laissez-faire & A & $0-5$ years & 239 & 3.56 & 1.33 & 3.509 & $.008 *$ & $\mathrm{~A}<\mathrm{B}$ \\
\hline & & $\mathrm{B}$ & $6-10$ years & 55 & 4.29 & 1.56 & & & \\
\hline & & $\mathrm{C}$ & $11-15$ years & 36 & 3.73 & 1.28 & & & \\
\hline & & $\mathrm{D}$ & $16-20$ years & 22 & 3.79 & 1.07 & & & \\
\hline & & $\mathrm{E}$ & 21 and over years & 55 & 3.85 & 1.18 & & & \\
\hline \multirow[t]{10}{*}{ Work Motivation } & Intrinsic Motivation & A & $0-5$ years & 239 & 3.61 & .84 & 1.724 & .144 & - \\
\hline & & B & $6-10$ years & 55 & 3.68 & .95 & & & \\
\hline & & $\mathrm{C}$ & $11-15$ years & 36 & 3.67 & .69 & & & \\
\hline & & $\mathrm{D}$ & 16-20 years & 22 & 3.55 & 1.10 & & & \\
\hline & & $\mathrm{E}$ & 21 and over years & 55 & 3.94 & .81 & & & \\
\hline & Extrinsic Motivation & A & $0-5$ years & 239 & 3.17 & .69 & 1.874 & .114 & - \\
\hline & & B & $6-10$ years & 55 & 3.31 & .87 & & & \\
\hline & & $\mathrm{C}$ & $11-15$ years & 36 & 3.03 & .65 & & & \\
\hline & & $\mathrm{D}$ & $16-20$ years & 22 & 3.18 & .66 & & & \\
\hline & & $\mathrm{E}$ & 21 and over years & 55 & 3.39 & .74 & & & \\
\hline
\end{tabular}

Note. ${ }^{*} \mathrm{p}<.05$. 
As could be seen in Table 4, as result of the one-way variance analysis (ANOVA) performed to determine whether the management style perceptions and work motivation levels of the employees working in the provincial organization of the General Directorate of Sports differed according to duration of service; it was determined that only the dimensions of authoritarian management style $(\mathrm{F}=3.701 ; \mathrm{p}<.05)$ and the laissez-faire management style $(\mathrm{F}=3.509 ; \mathrm{p}<.05)$ differed significantly. Furthermore, it was noticed that there was no significant difference in the sub-dimensions of work motivation of the employees working in the provincial organization of the General Directorate of Sports according to the duration of service. The Levene's test was used to examine whether the variances were homogeneous before performing the multiple comparison test. It was found that the variances in the dimensions of the authoritarian management style $(L F=2.088 ; \mathrm{p}>.05)$ and laissez-faire management style ( $\mathrm{LF}=2.366 ; \mathrm{p}>.05)$ were homogeneous; and the LSD test used to determine among which groups there was significant difference. When Table 4 was analyzed, it was noticed that whereas the score averages in terms of the authoritarian management style sub-dimension as one of the management style sub-dimensions of the employees who had $0-5$ years duration of service $(\bar{X}=3.54$; SS=1.16) were determined to be lower than the employees with 6-10 years $(\bar{X}=3.97$; SS=1.49) and 21 and over $(\bar{X}=4.16$; SS=1.04), the averages of the employees who had 11-15 years duration of service $(\bar{X}=3.60 ; \mathrm{SS}=1.44)$ were determined to be lower than the employees with 21 and over duration of service $(\bar{X}=4.16$; SS=1.04). Moreover, the score averages in terms of the laissez-faire management style sub-dimension as one of the management style sub-dimensions of the employee who had $0-5$ years duration of service $(\bar{X}=3.56$; SS $=1.33)$ were determined to be lower than the employees with 6-10 years duration of service ( $\bar{X}=4.29$; $\mathrm{SS}=1.56)$.

One-way ANOVA and LSD test results performed to reveal the difference of management style perceptions and motivation levels of the employees carrying on their duties in provincial organization of General Directorate of Sports according to their titles were presented in Table 5.

Table 5. Distribution of employees' management style perceptions and motivation levels according to their titles

\begin{tabular}{|c|c|c|c|c|c|c|c|c|c|}
\hline & Variables & Tit & & $\mathrm{n}$ & $\overline{\bar{X}}$ & Std. Dev. & $\mathrm{F}$ & $\mathrm{p}$ & LSD \\
\hline \multirow{25}{*}{ Management Styles } & \multirow[t]{5}{*}{ Authoritarian } & A & Sports Manager & 49 & 3.90 & 1.18 & \multirow[t]{5}{*}{1.828} & \multirow[t]{5}{*}{.123} & \multirow[t]{5}{*}{-} \\
\hline & & B & Sports /Sports Training Specialist & 61 & 3.67 & 1.38 & & & \\
\hline & & $\mathrm{C}$ & Officer & 158 & 3.60 & 1.25 & & & \\
\hline & & $\mathrm{D}$ & Coach & 74 & 3.98 & 1.26 & & & \\
\hline & & $\mathrm{E}$ & Other Employees & 65 & 3.53 & 1.11 & & & \\
\hline & \multirow[t]{5}{*}{ Protective } & A & Sports Manager & 49 & 5.31 & 1.04 & \multirow[t]{5}{*}{.583} & \multirow[t]{5}{*}{.675} & \multirow[t]{5}{*}{-} \\
\hline & & $\mathrm{B}$ & Sports /Sports Training Specialist & 61 & 5.27 & 1.14 & & & \\
\hline & & $\mathrm{C}$ & Officer & 158 & 5.31 & 1.18 & & & \\
\hline & & $\mathrm{D}$ & Coach & 74 & 5.52 & 1.00 & & & \\
\hline & & $\mathrm{E}$ & Other Employees & 65 & 5.27 & 1.30 & & & \\
\hline & \multirow[t]{5}{*}{ Supportive } & $\mathrm{A}$ & Sports Manager & 49 & 5.62 & 1.10 & \multirow[t]{5}{*}{.453} & \multirow[t]{5}{*}{.770} & \multirow[t]{5}{*}{-} \\
\hline & & $\mathrm{B}$ & Sports /Sports Training Specialist & 61 & 5.57 & 1.31 & & & \\
\hline & & $\mathrm{C}$ & Officer & 158 & 5.64 & 1.35 & & & \\
\hline & & $\mathrm{D}$ & Coach & 74 & 5.83 & 1.18 & & & \\
\hline & & $\mathrm{E}$ & Other Employees & 65 & 5.58 & 1.47 & & & \\
\hline & \multirow[t]{5}{*}{ Collaborative } & A & Sports Manager & 49 & 5.45 & 1.08 & \multirow[t]{5}{*}{.798} & \multirow[t]{5}{*}{.527} & \multirow[t]{5}{*}{-} \\
\hline & & $\mathrm{B}$ & Sports /Sports Training Specialist & 61 & 5.36 & 1.31 & & & \\
\hline & & $\mathrm{C}$ & Officer & 158 & 5.44 & 1.20 & & & \\
\hline & & $\mathrm{D}$ & Coach & 74 & 5.65 & 1.14 & & & \\
\hline & & $\mathrm{E}$ & Other Employees & 65 & 5.31 & 1.31 & & & \\
\hline & \multirow[t]{5}{*}{ Laissez-faire } & A & Sports Manager & 49 & 3.92 & 1.27 & \multirow[t]{5}{*}{1.377} & \multirow[t]{5}{*}{.241} & \multirow[t]{5}{*}{-} \\
\hline & & $\mathrm{B}$ & Sports /Sports Training Specialist & 61 & 3.54 & 1.38 & & & \\
\hline & & $\mathrm{C}$ & Officer & 158 & 3.77 & 1.37 & & & \\
\hline & & $\mathrm{D}$ & Coach & 74 & 3.88 & 1.40 & & & \\
\hline & & $\mathrm{E}$ & Other Employees & 65 & 3.47 & 1.21 & & & \\
\hline \multirow[t]{10}{*}{ Work Motivation } & \multirow{5}{*}{ Intrinsic Motivation } & $\mathrm{A}$ & Sports Manager & 49 & 3.75 & .77 & \multirow[t]{5}{*}{4.724} & \multirow[t]{5}{*}{$.001 *$} & $\mathrm{~B}<\mathrm{D}$ \\
\hline & & $\mathrm{B}$ & Sports /Sports Training Specialist & 61 & 3.57 & .85 & & & $\mathrm{C}<\mathrm{D}$ \\
\hline & & $\mathrm{C}$ & Officer & 158 & 3.53 & .86 & & & $E<D$ \\
\hline & & $\mathrm{D}$ & Coach & 74 & 4.03 & .74 & & & \\
\hline & & $\mathrm{E}$ & Other Employees & 65 & 3.63 & .96 & & & \\
\hline & \multirow{5}{*}{ Extrinsic Motivation } & A & Sports Manager & 49 & 3.37 & .63 & 1.663 & .158 & - \\
\hline & & $\mathrm{B}$ & Sports /Sports Training Specialist & 61 & 3.22 & .75 & & & \\
\hline & & $\mathrm{C}$ & Officer & 158 & 3.12 & .73 & & & \\
\hline & & $\mathrm{D}$ & Coach & 74 & 3.32 & .77 & & & \\
\hline & & $\mathrm{E}$ & Other Employees & 65 & 3.15 & .66 & & & \\
\hline
\end{tabular}

Note. ${ }^{*} \mathrm{p}<.05$. 
As could be seen in the Table 5, as result of the one-way variance analysis (ANOVA) which was performed to determine whether the management style perceptions and work motivation levels of the employees working in the provincial organization of the General Directorate of Sports differed according to their title; it was determined that there was no significant difference in the sub-dimensions of the management styles. In addition, it was determined that there was a significant difference in the intrinsic motivation $(F=4.724 ; p<.05)$ dimension as one of the sub-dimensions of work motivation for the employees working in the provincial organization of the General Directorate of Sports according to their title. To determine the source of this difference, the Levene's test was used before performing the multiple comparison test. It was found that the variances in the dimension of intrinsic motivation $\left(\mathrm{L}_{\mathrm{F}}=1.266 ; \mathrm{p}>.05\right)$ was homogeneous; and the LSD was used to determine the significant difference in the groups. When Table 5 was analyzed, it was also found that the averages in the intrinsic motivation dimension of work motivation scale for the employees working as a coach $(\bar{X}=4.03 ; \mathrm{SD}=.74)$ were determined to be higher rather than the sports specialist/sports training specialists ( $\bar{X}=3.57 ; \mathrm{SD}=.85$ ), the officers $(\bar{X}=3.53 ; \mathrm{SD}=.86)$ and the other employees $(\bar{X}=3.63 ; \mathrm{SD}=.98)$.

One-way ANOVA and LSD test results performed to reveal the difference of management style perceptions and motivation levels of the employees carrying on their duties in provincial organization of General Directorate of Sports according to in-service trainings were presented in Table 6 .

Table 6. Distribution of employees' management style perceptions and motivation levels according to in-service training

\begin{tabular}{|c|c|c|c|c|}
\hline & \multirow[b]{2}{*}{ Variables } & & \multicolumn{2}{|l|}{ Work Motivation } \\
\hline & & & Intrinsic Motivation & Extrinsic Motivation \\
\hline \multirow[t]{10}{*}{ Management Styles } & Authoritarian & $\mathrm{r}$ & $.197^{* *}$ & $.259^{* *}$ \\
\hline & & $\mathrm{p}$ & .000 & .000 \\
\hline & Protective & $\mathrm{r}$ & $.343^{* *}$ & .059 \\
\hline & & $\mathrm{p}$ & .000 & .238 \\
\hline & Supportive & $\mathrm{r}$ & $.357^{* *}$ & .074 \\
\hline & & $\mathrm{p}$ & .000 & .137 \\
\hline & Collaborative & $\mathrm{r}$ & $.345^{* *}$ & .070 \\
\hline & & $\mathrm{p}$ & .000 & .158 \\
\hline & Laissez-faire & $\mathrm{r}$ & $.156^{* *}$ & $.227^{* *}$ \\
\hline & & $\mathrm{p}$ & .002 & .000 \\
\hline
\end{tabular}

Note. ${ }^{*} \mathrm{p}<.01 ; * \mathrm{p}<.05$.

According to the findings related to correlation analysis presented in Table 6: there was a significant and positive relationship between the intrinsic motivation and dimensions of the authoritarian management style $(\mathrm{r}=.197)$, protective management style ( $\mathrm{r}=.343)$, supportive management style $(\mathrm{r}=.357)$, collaborative management style $(\mathrm{r}=.345)$ and laissez-faire management style $(\mathrm{r}=.156)$. Whereas there was a significant and positive relationship between extrinsic motivation and the dimensions of the authoritarian management style $(\mathrm{r}=.259)$ and laissez-faire management style $(\mathrm{r}=.227)$, there was no significant relationship between the dimensions of protective management style, supportive management style and collaborative management style. According to this result, it was possible to mention that the intrinsic motivation levels increased as the management style perceptions of the employees working in the provincial organization of the General Directorate of Sports increased in all sub-dimensions, and the extrinsic motivation levels increased as the authoritarian and laissez-faire management perceptions increased.

\section{Discussion and Conclusion}

In this study, the statistical findings were determined in order to specify the relationship between the motivation levels and management style perceptions of the employees working in the provincial organization of the General Directorate of Sports. In this section of the study, the results obtained from analyzing the data were interpreted and suggestions were offered in the light of this information.

When the management style perceptions of the employees working in the provincial organization of the General Directorate of Sports were evaluated according to gender; it was determined that whereas there was no significant difference in the dimensions of authoritarian, protective, supportive and collaborative management styles, the significant difference was found in the dimension of laissez-faire management style in favor of the male employees (Table 1). According to this finding, it was possible to mention that the male employees 
perceived the laissez-faire management style more than the female employees. According to the study carried out by Cesur upon the management styles of the managers of secondary schools, no significant difference was found between the authoritarian, protective and supportive management perceptions of teachers in terms of their gender (Cesur, 2005). Similarly, in the study conducted by Arlı about the management styles of primary school managers, no significant difference was found between the authoritarian, protective, supportive and collaborative management style perceptions of the teachers in terms of gender (Arl1, 2007). In the study carried out by Yllmaz about the perceptions of leadership types and motivation of the employees, no significant difference was found between the leadership types (informative, fatherly, democratic, autocratic and fully released) and gender (Yilmaz, 2011).

In addition, there was no significant difference in the dimensions of intrinsic motivation and extrinsic motivation as the sub-dimensions of work motivation scale for the employees working in the provincial organization of the General Directorate of Sports (Table 1).

In the study carried out by Argon and Ertürk upon the perceptions related to intrinsic motivations and organizational identity of primary school teachers, no significant difference was found between the female and male teacher perceptions in terms of intrinsic motivation (Argon \& Ertürk, 2013). According to Herzberg's double-factor theory, the intrinsic motivational tools that motivated employees were related to the content of the work (Herzberg, Mausner, \& Snyderman, 1959). Considering that the gender variable was not included in the intrinsic motivation tool related to the content of the work, it could be mentioned that it did not cause a difference in perceptions. In the study carried out by Brislin, Kabigting, Macnab, Zukis and Worthley (2005) upon comparing the employee and manager perceptions related to working place motivation, it was concluded that intrinsic motivation did not change according to the gender (Brislin, Kabigting, Macnab, Zukis, \& Worthley, 2005). In the study carried out by Dündar, Özutku and Taşpınar (2017) about the effects of the intrinsic and extrinsic motivation, intrinsic and extrinsic motivation tools on the motivation of employees, no significant difference was found in terms of the motivation of employees (Dündar, Özutku, \& Taşpınar, 2017). In the study carried out by A $\breve{g c a}$ and Ertan (2008) upon the emotional attachment and intrinsic motivation relationship, it was noticed that the intrinsic motivations of the employees did not change according to gender (Ağca \& Ertan, 2008). These findings supported the findings of our study. Whereas no significant difference was determined between extrinsic motivation and gender in the study carried out by Yusein on the relationship between organizational attachment and motivation, a significant difference was found between the intrinsic motivation sub-dimension and gender. It was determined that female employees had a higher level of intrinsic motivation (Yusein, 2013). This finding also supported our study partially.

When the management style perceptions of the employees working in the provincial organization of the General Directorate of Sports were evaluated in terms of age, it was noticed that whereas no significant difference was found in the authoritarian, protective, supportive and laissez-faire management style dimensions as the management styles sub-dimensions of the employees according to age, a significant difference was determined in the collaborative management style $(\mathrm{F}=2.318 ; \mathrm{p}<.05)$ in terms of age (Table 2$)$.

The score averages of the collaborative management style sub-dimension for the employees in 36-40 age group were found to be higher rather than the employees in $20-25,26-30,31-35$ and $41-45$ age groups. It was possible to mention that the employees in the middle age group adopted collaborative management style more. In the study carried out by Arlı on the management styles of the primary school managers, the perceptions related to collaborative management styles were evaluated in terms of age, and no significant difference was found (Arl, 2007).

It was determined that there were significant differences between intrinsic motivation $(\mathrm{F}=3.901 ; \mathrm{p}<.05)$ and extrinsic motivation $(\mathrm{F}=2.257 ; \mathrm{p}<.05)$ dimensions as the sub-dimensions of work motivation for the employees working in the provincial organization of the General Directorate of Sports in terms of age.

In the intrinsic motivation dimension of the work motivation scale, whereas the averages of the employees in 46 years and older were determined to be higher than the employees in the 20-25, 26-30, 31-35 and 41-45 age groups, the averages of the employees in the $41-45$ age group were determined to be lower than the employees in the 26-30 and 36-40 age groups. In the study carried out by Ertürk (2016) about the work motivations of the teachers, a significant difference was found between the perceptions of gender and intrinsic motivation. It was also determined that the intrinsic motivation perceptions of the teachers in 41 years and older age group were higher rather than the ones in 20-30 age group (Ertürk, 2016). In the study carried out by Kaş (2012) about the intrinsic and extrinsic motivation factors and organizational attachments of the employees, it was found that motivations of the employees in 36-41 age group were higher than the employees especially under the age of 36 
(Kaş, 2012). Furthermore, in the study carried out by Ağca and Ertan (2008), the findings were found similar to this study's findings, and it was determined that the perceptions of the employees related to intrinsic motivation changed according to age (A ğca \& Ertan, 2008).

In terms of the extrinsic motivation dimension, whereas the score averages of the employees in the 20-25 age group were determined to be higher than the employees in the 36-40 and 41-45 age group, the averages of the employees in 46 years and older were determined to be higher than the employees in 31-35, 36-40 and 41-45 age groups. It was possible to mention that the employees in 20-25 young age group recognized the working place and satisfied with the opportunities provided by the organization because they had just started to work life. In addition, it could be said that the middle-aged employees in 46 years and older group adopted their organizations more and their social motivations were higher because they were more conscious and experienced in their working lives. In the study conducted by Kaş (2012) on the intrinsic and extrinsic motivation factors and organizational attachments of the employees, it was determined that the employees in 42 years and older age group had higher intrinsic and extrinsic motivation levels (Kaş, 2012). In the study carried out by Ertürk upon the work motivations of the teachers, a significant difference was found between the perception of age and extrinsic motivation. It was also determined that the extrinsic motivation perceptions of the teachers in 41 years and older were higher than the extrinsic motivation perceptions of teachers in the 20-30 age group, and the extrinsic motivation perceptions of the teachers in 41 years and older were higher than the extrinsic motivation perceptions of teachers in the 31-40 age group (Ertürk, 2016).

When the management style perceptions of the employees working in the provincial organization of the General Directorate of Sports were evaluated according to educational status; it was found that whereas no significant difference was found in the protective, supportive, collaborative and laissez-faire dimensions as the management style sub-dimensions, a significant difference was determined in the authoritarian management style $(\mathrm{F}=3.660$; $\mathrm{p}<.05)$. The score averages of the authoritarian management style sub-dimension $(\bar{X}=4.04 ; \mathrm{SD}=1.25)$ as one of the management style sub-dimensions for the secondary school graduated employees were found to be higher than the university graduated employees $(\bar{X}=3.61 ; \mathrm{SD}=1.24)$ (Table 3$)$. As the education level increased, the authoritarian management style perceptions of the employees decreased. In the study carried out by Teyfur on the perceptions related to management styles adopted by the primary school managers and the evaluation of school managers' management skills by the parents, it was determined that the managers who had a postgraduate degree adopted less authoritarian management style (Teyfur, 2011).

It was determined that there was no significant difference in the intrinsic and extrinsic motivation dimensions of work motivation for the employees working in the provincial organization of the General Directorate of Sports in terms of educational status. In the study conducted by Ertürk on the teachers' work motivations, no significant difference was found between the educational status and intrinsic and extrinsic motivation dimensions of teachers (Ertürk, 2016).

When the management style perceptions of the employees working in the provincial organization of the General Directorate of Sports were evaluated in terms of duration of service; it was found that whereas no significant difference was found in the protective, supportive and collaborative management style dimensions for the employees according to the duration of service, a significant difference was determined in the authoritarian management style $(\mathrm{F}=3.701 ; \mathrm{p}<.05)$ and laissez-faire management style $(\mathrm{F}=3.509 ; \mathrm{p}<.05)$ dimensions. While the score averages of the authoritarian management style sub-dimension as one of the management style sub-dimensions for the employees who had 0-5 years duration of service ( $\bar{X}=3.54$; SS=1.16) were determined to be lower than the employees who had 6-10 years $(\bar{X}=3.97$; SS $=1.49)$ and 21 and over years duration of service $(\bar{X}=4.16 ; \mathrm{SS}=1.04)$, the averages of the employees who had $11-15$ years duration of service $(\bar{X}=3.60 ; \mathrm{SS}=1.44)$ were determined to be lower than the employees with 21 and over years duration of service $(\bar{X}=4.16$; SS $=1.04)$. In addition, the score averages of the laissez-faire management style sub-dimension for the employees who had $0-5$ years duration of service $(\bar{X}=3.56 ; \mathrm{SS}=1.33)$ were determined to be lower than the employees with $6-10$ years duration of service ( $\bar{X}=4.29 ; \mathrm{SS}=1.56$ ). In the light of the aforementioned data, it was possible to mention that the laissez-faire management style perceptions of the employees who had a short duration of service were lower than the employees who had a longer duration of service, and as the duration of time increased, the authoritarian management style perception decreased.

In the study conducted by Teyfur on the perceptions related to management styles adopted by the primary school managers, it was observed that the managers with seniority changing between 5 years and 16-20 years behaved more authoritarian (Teyfur, 2011).

When the management style perceptions of the employees working in the provincial organization of the General 
Directorate of Sports were evaluated according to their titles; no significant difference was found in the management style sub-dimensions of the employees.

In addition, it was determined that there was significant difference in the intrinsic motivation $(F=4.724 ; \mathrm{p}<.05)$ dimension as one of the sub-dimensions of the work motivation for the employees working in the provincial organization of the General Directorate of Sports according to their title. The averages in the intrinsic motivation dimension for the employees working as a coach $(\bar{X}=4.03 ; \mathrm{SD}=.74)$ were determined to be higher than the sports specialist/sports training specialists $(\bar{X}=3.57 ; \mathrm{SS}=.85)$, the officers $(\bar{X}=3.53 ; \mathrm{SD}=.86)$, and the other employees $(\bar{X}=3.63 ; \mathrm{SD}=.98)$.

In the study carried out by Ağca and Ertan (2008) for examining the emotional attachment and intrinsic motivation relationship of 402 people working in hotel business, a significant relationship was found between the section employees and their intrinsic motivations. The intrinsic motivations of the managers were found to be lower than the employees (A ğca \& Ertan, 2008).

When the relationship between the management style perceptions and motivation levels of the employees working in the provincial organization of the General Directorate of Sports were observed; it was noticed that whereas a significant and positive relationship was found between the perceptions of intrinsic motivation and the authoritarian management style $(\mathrm{r}=.197)$, the protective management style $(\mathrm{r}=.343)$, the supportive management style $(\mathrm{r}=.357)$, the collaborative management style $(\mathrm{r}=.345)$ and the laissez-faire management style $(\mathrm{r}=.156)$ dimensions, a significant and positive relationship was found between the extrinsic motivation and the authoritarian management style ( $\mathrm{r}=.259)$ and the laissez-faire management style ( $\mathrm{r}=.227)$ dimensions. According to this result, it was possible to mention that the intrinsic motivation levels increased as the perceptions of the management styles of the employees working in the provincial organization of the General Directorate of Sports increased in all sub-dimensions, and the extrinsic motivation levels increased as the authoritarian and laissez-faire management perceptions increased.

A good management approach was important in sport organizations as in all other organizations. The management style administered to increase employees' motivation levels undoubtedly plays a major role. In this study, a significant and positive relationship was found between the management style perceptions of the employees and their intrinsic and extrinsic motivation levels. It was possible to mention that adopted management styles not only affected the motivation levels of the employees, but also affected their performances, morales, organizational attachments and work satisfaction.

\section{References}

Adair, J. (2003). Effective motivation (S. Uyan, Trans.). İstanbul: Babıali Culture Publishing.

Ağca, V., \& Ertan, H. (2008). The relationship between affective commitment and intrinsic motivation: a study in hotels with five stars in Antalya. Afyon Kocatepe University Journal of Economics and Administrative Sciences, 10(2), 135-156.

Akat, İ. (1994). Business administration. İstanbul: Beta Publishing.

Argon, T., \& Ertürk, R. (2013). Intrinsic motivations of primary school teachers and their perceptions of organizational identity. Educational Administration: Theory and Practice, 19(2), 159-179.

Arl1, D. (2007). Analysis of primary school managers' management styles according to some variables. Master's thesis, University of Ege, İzmir, Turkey. Retrieved from https://tez.yok.gov.tr/UlusalTezMerkezi/

Aytürk, N. (2003). Management art. succesful management and management techniques. Ankara: Yarg1 Publishing.

Başaran, İ. E. (1982). Organizational behavior. Ankara: Ankara University Faculty of Education Publishing.

Başaran, İ. E. (2004). Human relations in management. Ankara: Nobel Academic Publishing

Başaran, İ. E. (2008). Turkish education system and school management. Ankara: Ekinoks Publishing.

Brief, A. P., \& Aldag, R. J. (1977). The intrinsic extrinsic dichotomy toward conceptual clarity. Academy of Management Review, 2(3), 496-500. https://doi.org /10.5465/amr.1977.4281861

Brislin, R. W., Kabigting, F., Macnab, B., Zukis, B., \& Worthley, R. (2005). Evolving perceptions of Japanese workplace motivation. International Journal of Cross-Cultural Management, 5(1), 87-103. https://doi.org/10.1177/1470595805050829

Bursalığlu, Z. (1994). New structure and behavior in school management. Ankara: Pegem Publishing. 
Cem, C. (1971). Management style. Journal of Amme, 4(1), 91-103.

Cesur, M. (2005). Management styles of high school principals in Kastamonu province. Master's thesis, University of Ankara, Ankara, Turkey. Retrieved from https://tez.yok.gov.tr/UlusalTezMerkezi/

Çakmak Yıldızhan, Y. (2012). Determination of the management styles the general directorate of sport in the central organization. Doctoral dissertation, University of Gazi, Ankara, Turkey. Retrieved from https://tez.yok.gov.tr/UlusalTezMerkezi/

Davis, K. (1981). Human behavior at work. organizational behavior. New York: NY, Mc Graw Hill.

Davis, K. (1988). Human behavior in business, organizational behavior (K. Tosun, Trans.). İstanbul: Yön Press.

Dick, G., \& Metcalfe, B. (2001). Managerial factors organizational commitment, The International Journal of Public Sector Management, 14(2), 111-128. https://doi.org/10.1108/09513550110387336

Dündar, S., Özutku, H., \& Taşpinar, F. (2017). The effects of intrinsic and extrinsic motivation tools on employees' motivations: an empirical investigation. Journal of Commerce \& Tourism Education Faculty, 2, $105-119$.

Erdoğan, G. (2004). School management teaching leadership. İstanbul: Sistem Publishing.

Ertürk, R. (2016). Work motivation of teachers. Journal of Education: Theory and Practical Research, 2(3), 115.

Herzberg, F., Mausner, B., \& Snyderman, B. B. (1959). The motivation to work (2nd ed.). New York: John Wiley $\&$ Sons.

Hersey, P., \& Blanchard, K. (1982). Management of organizational behavior: Utilizing human resources. USA: Prentice-Hall Incorporated. https://doi.org/10.1177/105960117700200419

İmamoğlu, A. F. (1992). Meaning and importance of sport management in functional perspective. Gazi Journal of Faculty of Education, 8(1), 21-34.

Kara, Z. (2015). The effects of organisational commitment levels of employees on working motivation and an application. Master's thesis, University of Osmangazi, Eskişehir, Turkey. Retrieved from https://tez.yok.gov.tr/UlusalTezMerkezi/

Kaş, L. (2012). The relation between organizational commitment of employees and Herzberg's elements of internal and external motivation: An application in five-star hotels in Belek. Master's thesis, University of Gazi, Ankara, Turkey. Retrieved from https://tez.yok.gov.tr/UlusalTezMerkezi/

Kazmier, L. J. (1979). Principles of business management (C. Cem, D. Canman, S. Büyükdavas, E. Eray, C. Tutum, \& Ü. Polat, Trans.). Ankara: TODAİE Press.

Latham, G. G., \& Pinder, C. C. (2005). Work motivation theory and resaerch at the dawn of the twenty-first century. Annual Review of Psychology, 56(1), 485-516. https://doi.org/10.1146/annurev.psych.55.090902.142105

Likert, R. (1967). The human organization: its management and value. New York, NY: Mc Graw Hill.

Luthans, F. (2001). Organizational behaviour. Singapore: Mc Graw Hill.

Mottaz, J. C. (1985). The relative importance of intrinsic and extrinsic rewards as determinants of wok satisfaction. The Sociological Quarterly, 26(3), 365-385.

Nurcahyo, B., Nur'ainy, R., \& Sariyati. (2011). Effect of intrinsic motivation on consumer brand evaluation: the influence of motive, involvement, and need for cognition. Global Business and Management Research: An International Journal, 3(3\&4), 231-246.

Öztekin, A. (2002). Management science. Ankara: Siyasal Press.

Paletta, A., \& Vidoni, D. (2006). Italian school managers: A complex identity. Leadershap and Management. ISEA, 34(1), 46-71.

Peker, Ö., \& Aytürk, N. (2000). Effective management skills. Ankara: Yarg1 Publishing.

Schein, E. H. (1978). Organizational psychology (M. Tosun Trans.). Ankara: TODAİE Press.

Şimşek, M. S., Akgemci, T., \& Çelik, A. (2003). Introduction to behavioral sciences and behavior in organizations (3th ed.). Konya: AdımPress.

Teyfur, M. (2011). Investigation of elementary school administrators? perceived administrative styles and 
administrative skills of school administrators according to parents. Doctoral dissertation, University of Atatürk, Erzurum, Turkey. Retrieved from https://tez.yok.gov.tr/UlusalTezMerkezi/

Tosi, H. L., Rizzo, J. R., \& Carroll, S. J. (1995). Managing organizational behavior. USA: Blackwell Publishers.

Urlu, R. (2002). Administrative approaches of school principals. Master's thesis, University of Niğde, Niğde, Turkey. Retrieved from https://tez.yok.gov.tr/UlusalTezMerkezi/

Yilmaz, M. K. (2011). The relationship between employee perception to leadership styles and motivation: A research over private and public sector employees. Master's thesis, University of Ege, İzmir, Turkey. Retrieved from https://tez.yok.gov.tr/UlusalTezMerkezi/

Yusein, R. (2013). The relationship between organisational commitment and motivation. Master's thesis, University of Gazi, Ankara, Turkey. Retrieved from https://tez.yok.gov.tr/UlusalTezMerkezi/

\section{Copyrights}

Copyright for this article is retained by the author, with first publication rights granted to the journal.

This is an open-access article distributed under the terms and conditions of the Creative Commons Attribution license (http://creativecommons.org/licenses/by/4.0/). 